\title{
L5-S1 SURVIVAL AFTER INTERBODY FUSION BY LATERAL APPROACH UNTIL L5 IN DEGENERATIVE DISEASE
}

\author{
SOBREVIDA DE L5S1 APÓS ARTRODESE INTERSOMÁTICA VIA LATERAL ATÉ L5 NA DOENÇA \\ DEGENERATIVA
}

\section{SUPERVIVENCIA DE L5-S1 DESPUÉS DE FUSIÓN INTERSOMÁTICA POR ACCESO LATERAL HASTA L5 EN ENFERMEDAD DEGENERATIVA}

Fernando Toni Marcelino da Silva, ${ }^{1}$ Luis Marchi, ${ }^{1}$ Gabriel Pokorny, ${ }^{1}$ Rodrigo Amaral, ${ }^{1}$ Rubens Jensen ${ }^{1}$, Luiz Pimenta

1. Instituto de Patologia da Coluna (IPC), São Paulo, SP, Brazil.

\begin{abstract}
Objectives: Whether or not to include L5-S1 in multiple level lumbar fusions is not yet a consensus in the literature. The option to preserve L5-S1 maintains the mobile segment and the possibility of a natural fit to the sagittal alignment of the lumbar spine. However, a long fusion above L5-S1 may accelerate the degenerative process and an extension to the sacrum may be necessary in the future. In this study, we evaluated the survival of the L5-S1 level after lateral lumbar interbody fusion (LLIF) of 3-4 levels up to L5 and attempted to identify risk factors that could guide the selection of cases. Methods: Retrospective study in a single center. Inclusion: Patients that submitted to interbody fusion (LLIF) from 3-4 levels to L5 due to degenerative spine disease with at least 5 years of follow-up. Exclusion: L5 sacralization or L5-S1 disc ankylosis. We evaluated the reoperation rate including L5-S1 disc. We reviewed the preoperative images regarding coronal Cobb angle, lumbar lordosis, pelvic incidence; distal fractional curve; radiographic classification of DDD (modified by Weiner and Pfirrmann), as well as demographics parameters. These parameters were compared between the case group (reoperated) and the control group. Results: Forty-seven patients were included achieving a success rate of inclusion of $81 \%$; the mean age was 69.1 years, $83 \%$ were women, and the mean of operated levels was 3.2. The survival rate of L5-S1 level was $89.6 \%$ at 5-year follow-up. No differences were found between the groups regarding the parameter evaluated. Conclusions: The L5-S1 survival rate was 896\% after LLIF of 3-4 levels up to L5 at 5-year follow-up. Statistically no risk factors were found to warrant preoperative inclusion of L5-S1. Level of Evidence III; Retrospective Study.
\end{abstract}

Keywords: Spine; Intervertebral Disc Degeneration; Spinal Fusion; Intervertebral Disc; Follow-Up Studies.

\section{RESUMO}

Objetivos: Incluir ou não o nível L5-S1 nas artrodeses lombares de múltiplos níveis ainda não é consenso na literatura. A opção de preservar L5S1 mantem o segmento móvel e a possibilidade de um ajuste natural ao alinhamento sagital da coluna lombar artrodesada. Porém, uma fusão longa acima de L5S1 pode acelerar seu processo degerativo e uma extensão ao sacro pode ser necessária futuramente. Neste estudo avaliamos a sobrevida do nível L5S1 após fusão intersomática por via lateral (LLIF) de 3-4 níveis até L5 e tentamos identificar fatores de risco que possam guiar a seleção dos casos. Métodos: Estudo retrospectivo, em um único centro. Inclusão: pacientes submetidos a artrodese intersomática por LLIF de 3-4 níveis até L5 por doença degenerativa da coluna com ao menos cinco anos de seguimento. Exclusão: L5 sacralizada ou disco L5S1 anquilosado. Avaliamos a taxa de reoperação incluindo o disco L5S1. Revisamos as imagens pré-operatórias quanto: ângulo de Cobb coronal; Iordose lombar; incidência pélvica; curva fracionada; classificações radiográficas de DDD (Weiner modificada e Pfirrman), além dos parâmetros demográficos. Tais parâmetros foram comparados entre o grupo caso (reoperados) e grupo controle. Resultados: 47 pacientes incluídos com uma taxa de sucesso de inclusão de 81\%, idade média 69,1 anos, 83\% mulheres, média de 3,2 níveis operados. Taxa de sobrevida do nível L5S1 foi de 89,6\% em cinco anos de seguimento. Não encontramos significância estatística entre os grupos nos parâmetros avaliados. Conclusão: A taxa de sobrevida de L5S1 foi de 89,6\% após LLIF de 3-4 níveis até L5 em cinco anos de seguimento. Estaticamente não foram encontrados fatores de risco que justifiquem inclusão pré-operatória de L5S1. Nível de Evidência III; Estudo Retrospectivo.

Descritores: Coluna Vertebral; Degeneração do Disco Intervertebral; Fusão Vertebral; Disco Intervertebral; Seguimentos.

\section{RESUMEN}

Objetivos: Objetivos: La inclusión o no de L5-S1 en fusiones lumbares de múltiples niveles aún no es un consenso en la literatura. La opción de preservar L5-S1 mantiene el segmento móvil y la posibilidad de un ajuste natural a la alineación sagital de la columna lumbar. Sin embargo, una fusión larga por encima de L5-S1 puede acelerar el proceso degenerativo y puede ser necesaria una extensión al sacro en el futuro. En este estudio, evaluamos la supervivencia del nivel L5-S1 después de la fusión intersomática lumbar lateral (LLIF) de 3-4 niveles hasta L5 e intentamos identificar los factores de riesgo que podrían guiar la selección de casos. Métodos: Estudio retrospectivo en un solo centro. Inclusión: Pacientes que se sometieron a fusión intersomática (LLIF) de 3-4 niveles a L5 debido a enfermedad degenerativa de la columna vertebral con al menos 5 años de seguimiento. Exclusión: Sacralización L5 o anquilosis del disco L5-S1. Se evaluó la tasa de reoperación incluyendo el disco L5-S1. Revisamos las imágenes preoperatorias con respecto al ángulo de Cobb coronal, lordosis lumbar, incidencia 
pélvica, curva fraccional distal, clasificación radiográfica DDD (modificada por Weiner y Pfirrmann), así como parámetros demográficos, . Estos parámetros se compararon entre el grupo de casos (nueva operación) y el grupo control. Resultados: Se incluyeron 41 pacientes que alcanzaron una tasa de éxito de inclusión del 81\%; la edad promedio fue de 69,1 años, el 83\% eran mujeres y el promedio de los niveles operados fue de 3,2. La tasa de supervivencia del nivel de L5-S1 fue del 89,6\% a los 5 años de seguimiento. No encontramos diferencias entre los grupos con respecto al parámetro evaluado. Conclusiones: La tasa de supervivencia de L5-S1 fue del 89,6\% después de LLIF de 3-4 niveles hasta $L 5$ a los 5 años de seguimiento. Estadísticamente, no se observaron factores de riesgo que justificaran la inclusión preoperatoria de L5-S1. Nivel de Evidencia III; Estudio Retrospectivo.

Descriptores: Columna Vertebral; Degeneración del Disco Intervertebral; Fusión Vertebral; Disco Intervertebral; Estudios de Seguimiento.

\section{INTRODUCTION}

With the aging of the population, degenerative pathologies, such as canal and/or foraminal lumbar stenosis with compression of the neural elements and degenerative adult deformities, are growing in frequency. Initially, most patients are treated for these pathologies in a conservative manner, but when these treatments are ineffective, we can propose the need for surgical approaches to improve the quality of life of the patients. Different techniques are described in the literature, such as simple decompression or decompression with arthrodesis, which can be performed by posterior only, anterior only, or combined approaches using interbody arthrodesis. ${ }^{1}$

When analyzing arthrodesis for the treatment of adult deformities of degenerative diseases of multiple levels of the lumbar spine, there is still no firm answer to the question about which distal level should be used for instrumentation, L 5 or the sacrum, and this question is the topic of studies by various authors. ${ }^{2-11}$

In the literature, primary arthrodesis to the sacrum is recommended in cases of advanced L5-S1 disc degeneration, significant lumbosacral obliquity, spondylolysis, or spondylolisthesis of L5, canal/foraminal stenosis in L5-S1, or prior decompressions at this level. Otherwise, using L5 as the distal level may be considered. ${ }^{11,12}$

The theoretical advantages of instrumentation to $L 5$ as compared to arthrodeses that extend to the sacrum, or even to the ilium, are preserving the mobile segment of L5-S1, a lesser surgery resulting in lower morbidity, and lower rates of pseudoarthrosis. But, it can accelerate the degeneration of the L5-S1 disc, causing disease of the adjacent distal disc, and thus, cause axial pain, foraminal compression, and/or loss of lumbar lordoses leading to sagittal misalignment and possibly requiring surgical revisions. ${ }^{2-7}$

Focused on reducing the morbidity and mortality of the classic accesses, new less invasive techniques have been developed, such as the lateral retroperitoneal transpsoas approach, also known as lateral lumbar interbody fusion (LLIF), as described by Pimenta in 2006. ${ }^{13}$ There are articles in the literature that show the effectiveness of using LLIF to treat degenerative scoliosis and indirect compression of neural elements. ${ }^{14-21}$

The objective of this article is to evaluate the survival of level L5$\mathrm{S} 1$ in cases of multilevel disc degeneration treated with 3- or 4-level LLIF with instrumentation to L5, with or without posterior supplementation. To do this we analyzed the rate of reoperation with extension of the arthrodesis to the sacrum or pelvis and also the possible predictive factors associated with the necessity of including L5-S1.

\section{METHODS}

This was a retrospective, non-randomized study conducted in a single center. The study protocol was evaluated and approved by the Institutional Review Board (83217817.7.0000.8054) and the requirement for the Informed Consent Form (ICF) was waived since this study was based on an analysis of already existing data, obtained for the purpose of diagnosis and medical follow-up, requiring only a review of medical records with information about the participants.

Inclusion criteria were cases of multilevel lumbar disc degeneration, with or without degenerative scoliosis, with or without canal/ foraminal stenosis; cases treated surgically with 3- or 4-level lumbar arthrodesis to L5 by lateral transpsoas approach (LLIF) with or without posterior supplementation; and a minimum follow-up of 5 years. Exclusion criteria were sacralization of L5 or preoperative ankylosis/fusion of L5-S1. Cases treated between 2004 and 2012 were analyzed by a single spine surgeon.

The medical records were reviewed and the rate of reoperation for extension of the arthrodesis to the sacrum or pelvis, including level L5-S1, of a previous arthrodesis within 5 years of follow-up was assessed. The patients were then separated into those who had undergone reoperation (case group) and those who had not (control group).

The following parameters were evaluated: coronal lumbar Cobb angle and the presence of a fractional curve (coronal angulation $>10^{\circ}$ at the L5-S1 level in the direction contrary to the lumbar curvature) in anterior posterior radiographs; lumbar lordosis (LL) measured between L5 and S1 and pelvic incidence (PI) in lateral radiographs; and the discrepancy between $\mathrm{PI}$ and $\mathrm{LL}(\mathrm{PI}$ $\mathrm{LL})$. The angles were measured using the CobbMeter application (CobbMeter CE, Regis Rigal, Version 2.5.2) operated through two Apple iPhone devices (Apple Inc., Cupertino, USA), one for each researcher. ${ }^{22}$ To evaluate the degree of preoperative L5-S1 disc degeneration, the lateral radiographs were analyzed using the modified Weiner radiographic classification ${ }^{23}$ and sagittal T2 weighted magnetic resonance images using the Pfirrmann radiographic classification. ${ }^{24}$

Pre- and postoperative radiological exams of the patients were analyzed by two independent researchers and documented by a third researcher. Discrepancies in the measurements were resolved by consensus.

The data obtained for the case group and the control group were compared by means of the Student's t, Mann Whitney, and Fisher's exact tests. The significance level was 95\% and the tests were conducted using SPSS Statistics version 18 software.

\section{RESULTS}

Initially, 58 patients were identified. Of these, three died before completing five years of follow-up and eight patients were lost during follow-up. Thus, 47 patients were included in the study (81\% inclusion rate). The demographic data of the group analyzed can be seen in Table 1. There were 39 (83\%) female patients and eight (17\%) male patients with a mean age of 69.1 years (43-86, minimum-maximum) and with an average of 3.2 operated levels per patient. Among the surgeries, 38 (81\%) were performed only by lateral approach and 9 (19\%) with some type of posterior supplementation.

Of the total number of cases included, 5 (10.6\%) progressed to

Table 1. Demographic and radiological data by total group and by subgroups.

\begin{tabular}{c|c|c|c|c}
\hline & Total (n=47) & $\begin{array}{c}\text { Control Group } \\
(\mathbf{n}=\mathbf{4 2})\end{array}$ & $\begin{array}{c}\text { Case Group } \\
(\mathbf{n}=\mathbf{5})\end{array}$ & $\mathbf{p}$-Value \\
\hline Sex (F/M) & $39 / 8$ & $34 / 8$ & $5 / 0$ & $\mathrm{P}=0.571$ \\
\hline Age $($ Years $)$ & $69( \pm 9)$ & $69( \pm 9)$ & $68( \pm 14)$ & $\mathrm{P}=0.427$ \\
\hline $\mathrm{PI}\left({ }^{\circ}\right)$ & $53.1( \pm 9.12)$ & $52.7( \pm 9.1)$ & $57.7(10.1)$ & $\mathrm{p}=0.188$ \\
\hline $\mathrm{LL}\left({ }^{\circ}\right)$ & $39( \pm 12.6)$ & $38.9( \pm 12.9)$ & $40.5( \pm 9,2)$ & $\mathrm{P}=0.432$ \\
\hline $\mathrm{PI}-\mathrm{LL}\left({ }^{\circ}\right)$ & $13.3( \pm 14)$ & $13.3( \pm 14.4)$ & $14.0( \pm 2.8)$ & $\mathrm{P}=0.472$ \\
\hline $\begin{array}{c}\text { Coronal Cobb } \\
\text { Angle }\left({ }^{\circ}\right)\end{array}$ & $18.4( \pm 11.1)$ & $18.6( \pm 11.4)$ & $16.7( \pm 6.8)$ & $\mathrm{P}=0.388$ \\
\hline $\begin{array}{c}\text { Fractional Curve } \\
(\text { Yes/No) }\end{array}$ & $12 / 31$ & $11 / 28$ & $1 / 3$ & $\mathrm{p}>0.999$ \\
\hline
\end{tabular}

*p-value for the comparison between the Control Group and the Case Group. 
reoperation of the L5-S1 level. Figure 1 shows the temporal distribution of the events of surgical approach of the adjacent distal level. One case was reoperated after six months, two after 18 months, another after four years, and the last in the fifth year of follow-up following arthrodesis by LLIF. The reoperations occurred on an average of 2.5 years after the first surgery, with $60 \%$ occurring in the first 2 years. As shown in the survival curve using the Kaplan-Meier method (Figure 2), the success rate of preservation of the L5-S1 level until the end of five years of follow-up was $89.4 \%$.

No male patients progressed to reoperation during the five-year follow-up period, but this did not represent a statistical difference $(p=0.571)$. In the comparison between the control group and the reoperated group (Table 1), we could not find statistical differences $(p>0.05)$ in relation to the other demographic data or to the various radiological parameters analyzed.
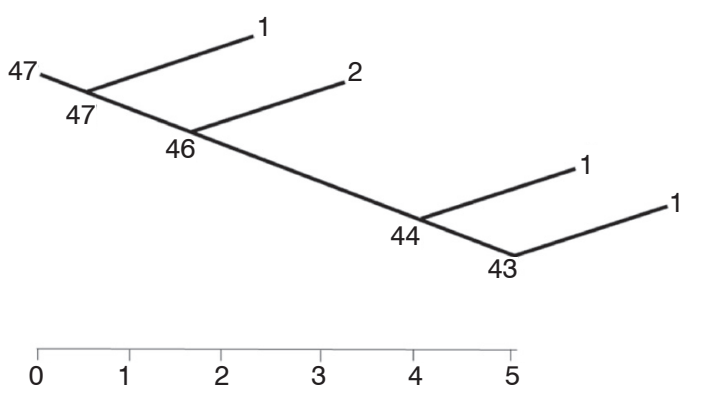

Follow-up time (years)

Figure 1. Tree graph respresenting the cases included and the reoperation events during the follow-up period. The continuous descending line represents the group free from reoperation of L5S1, while the diagonal lines represent the events and the number of cases reoperated during the study.

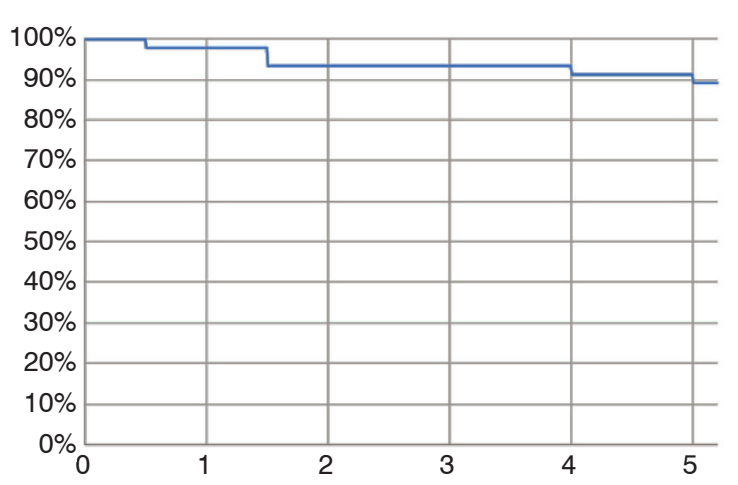

Figure 2. Kaplan-Maier survival curve representing the surgical survival rate of L5S1 in relation to postoperative follow-up time. At the end of 5 years the rate was $89.6 \%$

\section{DISCUSSION}

In multilevel arthrodeses that include the lumbar spine for the treatment of degenerative conditions, such as adult deformity or degenerative disc disease (DDD), there are still differences of opinion about the choice of the distal level of the arthrodesis, L5 or the sacrum.

Edwards et al. ${ }^{4}$ conducted a retrospective comparison of long arthrodeses to $L 5$ and to the sacrum for the treatment of deformities in patients similarly paired for possible confounding factors, all with healthy L5-S1 levels. In the study, it was noted that there really is an association between arthrodesis to $L 5$ and a greater incidence of subsequent disc degeneration at the L5-S1 level, but the rates of reoperation, more serious complications (among them pseudoarthrosis), and morbidity were higher in the group with arthrodesis to the sacrum, suggesting a causal effect of greater morbidity from the greater number of these surgeries in relation to arthrodesis to L5.

In another study of the same group, Kuhns et al. ${ }^{5}$ evaluated the fate of level L5-S1 arthrodesis to L5 for the treatment of thoracolumbar deformities with a minimum follow-up of five years. Thirty-one patients with an average of 10 fused levels (5-15, min-max) and a mean follow-up of 9.4 years (5-20.1, min-max) were evaluated. Of these, 7 patients $(23 \%)$ needed a new surgery to extend the arthrodesis to the sacrum. Another 6 patients (19.3\%) were indicated for extension of the arthrodesis but did not undergo surgery due to comorbidities that made the procedure inadvisable or to patient choice.

Cho et al. ${ }^{7}$ also retrospectively compared long arthrodeses to L 5 or to $\mathrm{S} 1$ for the treatment of degenerative scoliosis. Twenty-four patients were included in the arthrodesis to L5 group, with an average of 6.08 fused levels and an average follow-up of $3.5 \pm 1.7$ years $(2-8$, minmax). Four patients (16.6\%) required distal extension of the arthrodesis. Differently from Edwards et al., ${ }^{4}$ they did not observe a higher number of complications in the group with arthrodesis to the sacrum.

Brown et al. ${ }^{10}$ reported a revision rate of $19 \%$ in 16 patients with arthrodesis to $\mathrm{L} 5$ for the treatment of adult scoliosis with a mean follow-up of 2.7 years (0.7-6.5, min-max).

In our study, unlike the other studies mentioned, we used the LLIF technique to perform arthrodesis in our patients. In the literature, this technique has already proven to be effective in treating degenerative lumbar spine diseases such as adult deformities and multilevel DDD. ${ }^{14-21}$ A study conducted by Castro et al. ${ }^{15}$ concluded that the LLIF technique, even without posterior supplementation, was effective in treating mild adult scoliosis, providing satisfactory coronal and sagittal correction and clinical improvement of pain and function in spite of the high frequency of subsidence.

With the LLIF technique, we were unable to approach level L5-S1 because the iliac bone prevented access, so, if arthrodesis of this level were chosen in the primary surgery, another approach would have to be performed, anterior or posterior, prolonging surgical and anesthetic time and increasing patient risk. Thus, preserving level L5-S1 in arthrodesis by LLIF is desirable.

Only $5(10.6 \%)$ of the 47 patients analyzed in this study over five years of follow-up had to be reoperated for extension of the arthrodesis to the sacrum or pelvis, a rate lower that that found in the literature, presenting a five-year L5-S1 survival rate of $89.4 \%$. We observed the highest reoperation rate during the first two years of follow-up, representing $60 \%$ of the cases.

Our mean number of fused levels was 3.2 levels, fewer than that described in the other studies cited. Kuhns et al. ${ }^{5}$ associated longer arthrodeses with a greater risk of developing L5-S1 disc degeneration, which might explain our lower reoperation rate. However, in a recent study, Uribe et al. ${ }^{25}$ concluded that minimally invasive (MIS) arthrodesis techniques may allow smaller constructions as compared to the traditional open technique without affecting the clinical and radiographic outcomes.

We were not able to statistically relate any preoperative factor to a worse prognosis of the preservation of level L5-S1. Kuhns et al. ${ }^{5}$ reported longer arthrodeses and circumferential arthrodeses with greater disc degeneration at level L5-S1, while Cho et al. ${ }^{7}$ reported sagittal imbalance and preoperative hyperlordosis, but neither study related these parameters directly to the rate of reoperation.

Our study has several limitations. Because it is a retrospective study, we were not able to evaluate some preoperative data because they were not available in our files. We were only able to evaluate all the data for two patients who progressed to reoperation. Thus, we cannot guarantee with certainty that there are no factors for a worse prognosis for the preservation of level L5-S1. Additionally, we did not evaluate whether any patients with an indication of caudal extension of the arthrodesis for any reason could not or did not want to undergo surgery, but only if they progressed or not to reoperation. So, we may have overestimated the survival rate of level L5-S1. 


\section{CONCLUSION}

At the end of five years of follow-up, the preservation of L5S1 success rate in the treatment of multilevel lumbar degeneration without deformity using lateral transpsoas approach interbody arthrodesis was $89.6 \%$. Because of the low number of cases, it was not possible to discover predictive factors of the failure of the adjacent distal level following three- or four-level arthrodesis.
The authors Rodrigo Amaral and Rubens Jensen are NuVasive consultants. The author Luis Henrique Mattos Pimenta receives royalties from NuVasive. All other authors declare no potential conflict of interest related to the article.

CONTRIBUTION OF THE AUTHORS: Each author made significant individual contributions to this manuscript. FTMS (0000-0002-7851-0444)*, LM $(0000-0002-3447-0399)^{\star}$, and GP (0000-0002-7907-8032)* were the main contributors to the preparation of the manuscript. LP (0000-0002-5702-5431)*, RJ (0000-0002-2313-7793)*, RA (0000-0003-3007-0571)*, and FTMS performed the surgeries, followed-up with patients, and collected the clinical data. LM and GP evaluated the statistical analysis data, conducted the bibliographical research, and reviewed the manuscript. LP, RJ, RA and LM contributed to the intellectual concept of the study. *ORCID (Open Researcher and Contributor ID).

\section{REFERENCES}

1. Bridwell KH. Selection of instrumentation and fusion levels for scoliosis: where to start and where to stop. Invited submission from the Joint Section Meeting on Disorders of the Spine and Peripheral Nerves. J Neurosurg Spine. 2004;1(1):1-8.

2. Bridwell KH, Edwards CCII, Lenke LG. The pros and cons to saving the L5-S1 motion segment in a long scoliosis fusion construct. Spine (Phila Pa 1976). 2003;28(20):S234-42

3. Edwards CCII, Bridwell KH, Patel A, Rinella AS, Jung Kim Y, Berra AB, et al. Thoracolumbar deformity arthrodesis to L5 in adults: the fate of the L5-S1 disc. Spine (Phila Pa 1976). 2003;28(18):2122-31.

4. Edwards CCII, Bridwell KH, Patel A, Rinella AS, Berra A, Lenke LG. Long adult deformity fusions to L5 and the sacrum. A matched cohort analysis. Spine (Phila Pa 1976). 2004;29(18):1996-2005.

5. Kuhns CA, Bridwell KH, Lenke LG, Amor C, Lehman RA, Buchowisk JM, et al. Thoracolumbar deformity arthrodesis stopping at L5: fate of the L5-S1 disc, minimum 5-year follow-up. Spine (Phila Pa 1976). 2007;32(24):2771-6

6. Polly DW Jr, Hamill CL, Bridwell KH. Debate: to fuse or not to fuse to the sacrum, the fate of the L5-S1 disc. Spine (Phila Pa 1976). 2006;31(19S):S179-84

7. Cho KJ, Suk SI, Park SR, Jin HK, Sung WC, Young HY, et al. Arthrodesis to L5 versus $\mathrm{S} 1$ in long instrumentation and fusion for degenerative lumbar scoliosis. Eur Spine $\mathrm{J}$. 2009;18(4):531-7.

8. Sardar ZM, Ouellet JA, Fischer DJ, Skelly AC. Outcomes in Adult Scoliosis Patients Who Undergo Spinal Fusion Stopping at L5 Compared with Extension to the Sacrum. Evid Based Spine Care J. 2013;4(2):96-104.

9. Daniels AH, Koller H, Hiratzka SL, Mayer M, Meier O, Contag AG, et al. Selecting caudal fusion levels: 2 year functional and stiffness outcomes with matched pairs analysis in multilevel fusion to L5 versus S1. Eur Spine J. 2017;26(6):1645-51.

10. Brown KM, Ludwig SC, Gelb DE. Radiographic predictors of outcome after long fusion to L5 in adult scoliosis. J Spinal Disord. 2004;17(5):358-66.

11. Bridwell KH. Where to stop the fusion distally in adult scoliosis-L4, L5, or the sacrum? In: Pritchard DJ, ed. Instructional Course Lectures. Vol. 45. Rosemont, IL: American Academy of Orthopaedic Surgeons; 1996. p.101-7.

12. 12. Bridwell $\mathrm{KH}$. Osteotomies for fixed deformities in the thoracic and lumbar spine. In: Bridwell KH, Dewald RL, eds. The Textbook of Spinal Surgery, 2nd ed, vol. 1. Philadelphia: Lippincott-Raven; 1997. p.821-35.

13. Ozgur BM, Aryan HE, Pimenta L, Taylor WR. Extreme Lateral Interbody Fusion (XLIF): a novel surgical technique for anterior lumbar interbody fusion. Spine J. 2006:6(4):435-43.
14. Ozgur BM, Agarwal V, Nail E, Pimenta L. Two-year clinical and radiographic success of minimally invasive lateral transpsoas approach for the treatment of degenerative lumbar conditions. SAS J. 2010;4(2):41-6.

15. Castro C, Oliveira L, Amaral R, Marchi L, Pimenta L. Is the Lateral Transpsoas Approach Feasible for the Treatment of Adult Degenerative Scoliosis? Clin Orthop Relat Res. 2014;472(6):1776-83.

16. Anand N, Rosemann R, Khalsa B, Baron EM. Mid-term to longterm clinical and functional outcomes of minimally invasive correction and fusion for adults with scoliosis. Neurosurg Focus. 2010;28(3):E6.

17. Dakwar E, Cardona RF, Smith DA, Uribe JS. Early outcomes and safety of the minimally invasive, lateral retroperitoneal transpsoas approach for adult degenerative scoliosis. Neurosurg Focus. 2010;28(3):E8.

18. Isaacs RE, Hyde J, Goodrich JA, Rodgers WB, Phillips FM. A prospective, nonrandomized, multicenter evaluation of extreme lateral interbody fusion for the treatment of adult degenerative scoliosis: perioperative outcomes and complications. Spine (Phila Pa 1976). 2010;35(26):S322-30.

19. Mundis GM, Akbarnia BA, Phillips FM. Adult deformity correction through minimally invasive lateral approach techniques. Spine (Phila Pa 1976). 2010;35(26):S312-21.

20. Castellvi AE, Nienke TW, Marulanda GA, Murtagh RD, Santoni BG. Indirect Decompression of Lumbar Stenosis With Transpsoas Interbody Cages and Percutaneous Posterior Instrumentation. Clin Orthop Relat Res. 2014;472(6):1784-91.

21. Oliveira $L$, Marchi $L$, Coutinho E, Pimenta $L$. A radiographic assessment of the ability of the extreme lateral interbody fusion procedure to indirectly decompress the neural elements. Spine (Phila Pa 1976). 2010;35(26 Suppl):S331-7.

22. Marchi L, Fortti F, Amaral R, Oliveira L, Nogueira-Neto J, Jensen R, et al. Reproducibility and equivalence of cobbmeter application in the sagittal evaluation of the spine. Coluna/Columna. 2016;15(4):279-82.

23. Weiner DK, Distill B, Studenski S, Martinez S, Lomasney L, Bongiorni D. Does radiographic flexibility correlate with flexibility of the lumbar spine? J Am Geriatr Soc. 1994:42(3):257-63.

24. Pfirrmann CW, Metzdorf A, Zanetti M, Holder J, Boos N. Magnetic resonance classification of lumbar intervertebral disc degeneration. Spine (Phila Pa 1976). 2001;26(17):1873-8.

25. Uribe JS, Beckman J, Mummaneni PV, Okonkwo D, Nuley P, Wang MY, et al. Does MIS Surgery Allow for Shorter Constructs in the Surgical Treatment of Adult Spinal Deformity? Neurosurgery. 2017;80(3):489-97. 